\title{
SOEP
}

SOEPpapers

SOEPROAOrs
on Multidisciplinary Panel Data Research

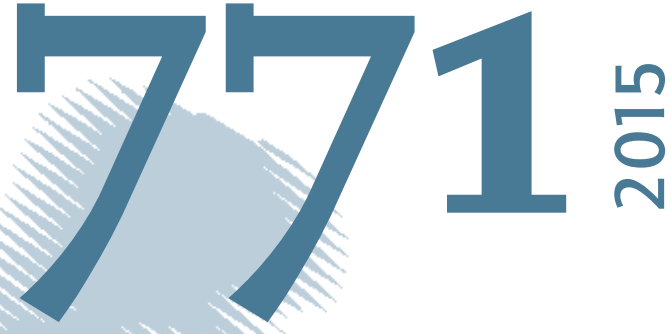

\section{Individual and Workplace-specific Determinants of Paid and Unpaid Overtime Work in Germany}


This series presents research findings based either directly on data from the German SocioEconomic Panel study (SOEP) or using SOEP data as part of an internationally comparable data set (e.g. CNEF, ECHP, LIS, LWS, CHER/PACO). SOEP is a truly multidisciplinary household panel study covering a wide range of social and behavioral sciences: economics, sociology, psychology, survey methodology, econometrics and applied statistics, educational science, political science, public health, behavioral genetics, demography, geography, and sport science.

The decision to publish a submission in SOEPpapers is made by a board of editors chosen by the DIW Berlin to represent the wide range of disciplines covered by SOEP. There is no external referee process and papers are either accepted or rejected without revision. Papers appear in this series as works in progress and may also appear elsewhere. They often represent preliminary studies and are circulated to encourage discussion. Citation of such a paper should account for its provisional character. A revised version may be requested from the author directly.

Any opinions expressed in this series are those of the author(s) and not those of DIW Berlin. Research disseminated by DIW Berlin may include views on public policy issues, but the institute itself takes no institutional policy positions.

The SOEPpapers are available at http://www.diw.de/soeppapers

\section{Editors:}

Jan Goebel (Spatial Economics)

Martin Kroh (Political Science, Survey Methodology)

Carsten Schröder (Public Economics)

Jürgen Schupp (Sociology)

Conchita D'Ambrosio (Public Economics)

Denis Gerstorf (Psychology, DIW Research Director)

Elke Holst (Gender Studies, DIW Research Director)

Frauke Kreuter (Survey Methodology, DIW Research Fellow)

Frieder R. Lang (Psychology, DIW Research Fellow)

Jörg-Peter Schräpler (Survey Methodology, DIW Research Fellow)

Thomas Siedler (Empirical Economics)

C. Katharina Spieß (Education and Family Economics)

Gert G. Wagner (Social Sciences)

ISSN: 1864-6689 (online)

German Socio-Economic Panel Study (SOEP)

DIW Berlin

Mohrenstrasse 58

10117 Berlin, Germany

Contact: Uta Rahmann | soeppapers@diw.de 
Individual and Workplace-specific Determinants of Paid and Unpaid Overtime Work in Germany

Ines Zapf

Ines Zapf, Institute for Employment Research, Regensburger Strasse 104, 90478 Nuremberg, Germany, E-Mail: Ines.Zapf@iab.de 


\title{
Individual and Workplace-specific Determinants of Paid and Unpaid Overtime Work in Germany
}

\section{JEL classification:}

$\mathrm{J} 21, \mathrm{~J} 24, \mathrm{~J} 81$

Keywords: Overtime work, internal flexibility

\begin{abstract}
:
In Germany, overtime work is a well-established instrument for varying working hours of employees and is of great importance for establishments as a measure of internal flexibility. However, not all employees are affected to the same degree by a variation of the work effort through overtime work. Besides socio-demographic factors, workplace-specific factors that provide information about the position of employees in the establishment play an important role, too. So far, we do not know enough how these workplace-specific factors are associated with overtime work. This question is at the center of this study. In the analysis, women and part-time employees are taken into account, while previous studies mostly focused on full-time employees and/or male workers. On the basis of the data of the German Socio-Economic Panel (SOEP), the results show a significant negative correlation between women and paid overtime and between part-time employees and unpaid overtime. If the employees performance is regularly assessed by a superior, paid overtime is less likely, while unpaid overtime becomes more likely. In executive positions, there is a significant positive correlation with paid and unpaid overtime work. Unpaid overtime is more likely with a growing autonomy in the employees' workplace, whereas paid overtime becomes less likely. However, the length of the training period on the job as well as job related burdens due to a job at risk and a limited employment contract seem to have no association with paid or unpaid overtime.
\end{abstract}




\section{Introduction}

In Germany, overtime work is a well-established instrument for varying working hours of employees in an establishment and is of great importance as a measure of internal flexibility (Bellmann/Gewiese 2003). In general, overtime hours are defined as working hours exceeding the contractually agreed regular working hours of employees (Gold 2002; Bellmann/Gewiese 2003; Anger 2006a). According to overtime work two types can be distinguished: definitive and transitory overtime work.

Definitive overtime work comprises paid and unpaid overtime. For paid overtime, employees receive a monetary, i.e. financial, compensation for the additional work (BundesmannJansen/Groß/Munz 2000; Bauer et al. 2004). In addition to the contractually defined hourly rates, this compensation can also include a premium; many collective agreements contain overtime pay provisions from the very first hour of overtime work (Bispinck 2005). Usually, there is a premium of 25 per cent on normal working days and 50 per cent on Sundays and public holidays (Anger 2006a). For unpaid overtime, however, there is no financial compensation.

Transitory overtime hours are additional hours worked that can be used up later, i.e. employees can take time off in lieu of overtime. As compared to definitive overtime hours, transitory overtime hours only change the distribution of the working hours over a certain period of time, while the number of working hours remains the same over the reference period (Bundesmann-Jansen/Groß/Munz 2000; Bauer et al. 2002, 2004; Koch 2001).

Establishments use definitive and transitory overtime work to adjust the working time of employees, especially in case of demand fluctuations. The adjustment of the amount of labour input is used without recourse to the external labour market. Therefore, the variation of working hours is also called an instrument of internal numerical flexibility and can be distinguished from external numerical flexibility by varying the number of employees. External numerical flexibility is defined as adjusting an establishments use of labour through hiring and firing, temporary employment or fixed-term contracts. Internal numerical flexibility is an alternative to measures of external numerical flexibility and is quite common among German establishments (Keller/Seifert 2006).

During the Great Recession, the global economic and financial crisis of the years 2008/09 working time flexibility played an important role to overcome the negative effects on the German labour market. According to the calculations of the Institute for Employment Research (IAB), the average annual working hours per employee was reduced by 44.5 hours in $2009(-3.3 \%)$ in comparison to 2008 . The reduction of paid overtime contributed 8.6 hours to this reduction, and the reduction of formerly accumulated hours on working time accounts, which can be called transitory overtime hours, contributed 8.0 hours (Fuchs et al. 2013).

However, not all establishments use overtime work to cope with economic and daily/seasonal demand fluctuations, and not every employee is affected by overtime work. 
Besides the establishments decision using overtime work, socio-demographic factors of employees determine whether employees do work overtime or not. In general, empirical studies show an increase of the share of employees working overtime and during the last years transitory overtime hours with a compensation with time-off got more important. In contrast, the importance of paid overtime declined, whereas it slightly increased for unpaid overtime (see e.g. Anger 2006b; Brautzsch/Drechsel/Schultz 2012; Hunt 2012). Brautzsch/Drechsel/Schultz (2012) show that in 2005, employees worked on average 11.7 overtime hours every month, and five years later even 12.3 hours. The amount of overtime compensated with time-off increased from 4.7 to 5.1 hours, and unpaid overtime rose from 2.9 to 3.2 hours, whereas paid overtime was only 1.5 and 1.8 hours, respectively.

So far, several studies on overtime work exist using multivariate analysis methods. It can be differentiated between studies that analyse the individual and structural determinants of overtime (cf. Bauer/Zimmermann 1999; Pannenberg/Wagner 2000; Schank/Schnabel 2004; Gold 2004) and those which deal with the socio-economic consequences of overtime work (cf. Pannenberg/Wagner 2001; Anger 2005a, 2006a; Pannenberg 2005). The results show that individual factors, such as the employee's age or level of qualification, are correlated with overtime work. The industry and the size of the establishment in which the employee works are also correlated with overtime work. As far as socio-economic consequences are concerned, it can be shown that especially unpaid overtime work has a positive influence on income mobility and the probability of a promotion. In this context, the argument has been put forward that investments in human capital are rather worthwhile in the form of overtime work which leads to positive returns in the future. But, studies also show that overtime work has a negative effect on health behaviour as well as the health of employees (cf. Van der Hulst/Geurts 2001; Taris et al. 2011).

Previous studies on the determinants of overtime work mainly refer to certain subgroups in the labour market, mostly full-time employees and/or male employees. Many studies do not take into account women and part-time employees, with a different labour market behaviour thus failing to perform a comprehensive analysis on overtime work. Furthermore, there is almost no evidence on recent trends on working overtime and the existing studies mainly concentrate on "classical" individual and establishment-specific factors, including age and qualification, the establishment size and industry. In contrast, workplace-specific factors, drawing conclusions from the employees' position in an establishment, such as leadership and responsibility, the level of autonomy and job related burdens, have so far not been considered enough. However, these aspects can constitute an important contribution for explaining overtime work.

This paper seeks to analyse these workplace-specific factors in order to gain major results for the determining factors of overtime work. In addition to information about gender and employment status, especially information about the extent of introduction on the job raising with the complexity of tasks, information about performance assessments by a superior, 
leadership position and responsibility, autonomy and job related burdens are integrated into the analysis. So far the existing studies only include some of these factors, leading to a limited understanding of the importance of workplace-specific factors. However, a common analysis is necessary to gain major insights on how those factors are associated with overtime work. We use the 2011 wave of the German Socio Economic Panel Study (SOEP) taking men and women in full-time and part-time employment into account. This wave provides unique information about workplace specific factors for which an association with paid and unpaid overtime work is concerned. Other waves of the SOEP do not include all relevant information for which an important contribution for explaining overtime work is expected. However, a panel data analysis is not possible.

This paper is subdivided into six chapters and concentrates on the explanation of paid and unpaid overtime work. Chapter 2 first points out theoretical considerations for explaining paid and unpaid overtime work. In the third chapter the hypotheses are presented, which will subsequently be reviewed empirically on the basis of the SOEP data. In chapter 4 follows a short description of the dataset and a documentation of the variables used. The methodological approach is also explained. In the fifth chapter, descriptive findings about the incidence of overtime work are presented. The results are shown for overtime that was compensated by time-off, overtime partly paid and partly compensated with time-off, paid overtime and unpaid overtime work. The determinants of paid and unpaid overtime work are identified by using probit models. Finally, in the sixth chapter, the results are summarised and their implications are also discussed in view of possible future developments.

\section{Theoretical Considerations}

In the following various theoretical approaches for explaining paid and unpaid overtime work are presented. These are the basis for the hypotheses presented in chapter 3 .

\section{Neoclassical Theory of Labour Supply}

According to the neoclassical theory of labour supply, employees generally decide between a certain level of income and the length of their leisure versus working time. Employees choose the working hours which maximise their benefits taking budget and household restrictions into account (Gerlach/Hübler 1987). In so far as the contractual working hours are lower than the working hours desired by the employee, the benefit is maximised by offering overtime work. In addition, remuneration in the form of an overtime premium can lead to a maximisation of benefits (Anger 2006a). Another motive why employees offer paid and unpaid overtime is to secure their jobs. The higher the risk of unemployment, the more are employees willing to work overtime in order to improve their position in the establishment and to reduce the probability of a job loss (Anger 2006a). (Un-)paid overtime is also worked if the length of the time required to complete job tasks is uncertain and a mismatch between the contractual hours and the hours actually worked arises. Unpaid overtime is also provided by employees with low productivity to complete assigned tasks or to catch up with the 
productivity of others. Team leaders may compensate occasionally absent or less productive employees by working additional unpaid hours (Bell/Hart 1999a; Bell et al. 2000).

\section{Neoclassical Theory of Labour Demand}

The neoclassical theory of labour demand emphasizes the cost advantage of paid and unpaid overtime as compared to an adjustment of the number of employees in case of demand fluctuations. The number of working hours is varied as compared to the number of persons if the marginal revenue product of labour of an additional hour worked is higher than if one more employee were hired (Gerlach/Hübler 1987). However, establishments only demand overtime work as long as the marginal gain exceeds the marginal costs of overtime work and these marginal costs are not higher than those of an adjustment of the number of employees (Gold 2004). In general, paid and unpaid overtime work is an important instrument for dealing with short-term and temporary demand changes and for keeping delivery deadlines. Overtime is also demanded when there are temporary staff shortages due to holidays or illness of employees (Bauer/Zimmermann 1999; Gold 2002; Bellmann/Gewiese 2003).

\section{Human Capital Theory}

According to the human capital theory, paid and unpaid overtime work can be considered as an (additional) investment in establishment-specific human capital. The latter is procured by obtaining or improving new capacities or capacities that already exist during the (extended) working hours (Becker 1962). Thus, paid and unpaid overtime contributes to an increase in human capital, which can lead to an increase of individual productivity and to obtain positive returns in the future, for example pay rises or promotions (Bell/Freeman 2001; Anger 2005a, 2008). Since establishments also invest in establishment-specific human capital of their employees, they are also interested in an extension of working hours to amortise investment costs (Becker 1962).

\section{Theory of Incentive Regulation and Theory of Deferred Compensation}

The theory of incentive regulation and the theory of deferred compensation assume a seniority remuneration of employees. According to these theories, younger employees are systematically underpaid at the beginning of their working life and older employees are systematically overpaid at the end of their employment relationship. It is assumed that especially younger employees have an incentive to work more by providing paid and unpaid overtime with the aim of remaining in the establishment. Thus they obtain positive returns in the future such as a higher salary through seniority remuneration systems (Lazear 1979; Anger 2005a).

\section{Tournament Theory}

According to the tournament theory, employees are remunerated on the basis of a ranking order in an establishment. Employees enter into a competition among each other, thus 
getting an incentive to increase their performance in order to achieve higher bonuses or rewards as e.g. future promotions to better paid positions. Establishments make use of this tournament model if an observation of the rank order is less costly than measuring individual performance (Lazear/Rosen 1981; Prendergast 1999; Anger 2005a). Therefore, as according to the theory of incentive regulation and the theory of deferred compensation, employees offer paid and unpaid overtime work to increase performance in order to obtain a better salary by promotion.

\section{Efficiency Wage Theory}

The efficiency wage theory explains an employees' productivity as a function of the wages paid. According to this theory, employers face incomplete information on the employees' productivity and are therefore willing to pay higher wages to avoid a decrease of productivity (Shapiro/Stiglitz 1984). In this context, overtime work can be interpreted as an expression of a higher productivity, so that employees receive remuneration above the market-clearing wage. A variant of the efficiency wage theory is the exchange approach. The relationship between employer and employee is characterised by gift exchanges which are not necessarily stipulated in the employment contract. Employers pay higher wages and in return employees work additional hours in the form of unpaid overtime exceeding the contractual working hours (Akerlof 1982, 1984; Bell/Hart 1999a; Bell et al. 2000; Anger 2006a).

\section{Signaling Theory}

The signaling theory assumes that employers do not have complete information about the performance and productivity of employees when they hire them. Hiring employees becomes an investment decision under uncertainty. However, the capacities of the applicant can be assessed on the basis of observed characteristics. These characteristics are either unalterable, such as gender (indices), or alterable, such as qualification (signals). During the recruitment process, the applicant with individual indices and signals faces the company's wage offer. However, signals on the applicant's side also cause costs, and one form of signal costs are working hours (Spence 1973). With longer working hours due to overtime work, employees signal a high value of their work, which can be expressed by effort, commitment, loyalty or motivation without additional remuneration (Anger 2006a, 2008). According to the signaling theory, the extent of unpaid overtime is also used by establishments in order to decide about promotions, pay rises and lay-offs. Since unpaid overtime can be monitored more easily than the employees' productivity, it is an important basis for decisions on career advancements.

\section{Hypotheses and Previous Findings}

In the context of the theoretical considerations, the following hypotheses concerning the influencing factors of overtime work are set forth. 
In spite of the fact that more and more women are gainfully employed, they still bear the greater part of family and household duties. Women mostly care for children and household, even if both partners are in employment (Behnke/Meuser 2005). Therefore, women often reduce their working hours also offering less paid or unpaid overtime. The human capital theory (Becker 1962) also provides an explanation for possible gender differences. On the one hand, women could be less interested and/or have poorer incentives to invest in establishment-specific human capital. Women often have shorter working hours and longer career interruptions, and therefore the chances of promotions or pay rises are estimated poorer. On the other hand, employers could be less interested in investing in human capital of women because of the reduced presence of female employees. Investment costs which would have to amortize occur less frequently then, which in turn reduces the incentive for women to provide overtime.

Hypothesis 1: For women, it is less likely to work paid and unpaid overtime hours.

\section{Employment Status}

Part-time employees perform less working hours, and in comparison to full-time employees, they are less available for the establishment. In case the employee works part-time voluntarily, benefit-maximising working hours are attained with a lower amount of working hours and therefore the supply of paid or unpaid overtime is limited. But even for employees who work part-time involuntarily, a negative impact on overtime work can be expected. Involuntary part-time employees can be less inclined to invest in human capital as investments are not worthwhile, for example due to a lack of demand for full-time jobs in an establishment.

Hypotheses 2: Part-time employees work paid and unpaid overtime less frequently than fulltime employees.

\section{Extent of introduction on the job}

Besides the qualification of employees, the extent of introduction on the job for new employees can be considered as a measure of the extent of the acquired establishmentspecific human capital. In case of a short introduction on the job, it can be assumed that only little (specific) knowledge and capacities are necessary to fulfil the required tasks. Therefore, no additional investments in establishment-specific human capital in the form of longer working hours are necessary. In case of a longer training period in the establishment or participation in special training programmes or courses to fulfil the required tasks, more establishment-specific human capital is procured. As a consequence it can be assumed that employees who only had a short introduction only make little further investments in human capital during the rest of their employment within the establishment. In contrast, employees who had a longer training period or attended special training programmes or courses will probably make human capital investments even after the initial training period in order to fulfil 
their job. In this group of employees, the working hours are extended by paid or unpaid overtime work to procure human capital. It can also be assumed that due to the higher time expenditure for training and/or for attending courses, there is less time for the actual job duties, which must be caught up by paid or unpaid overtime work. Furthermore, the more complex the tasks the more difficult it is for employees to plan the required time. In order to fulfil the tasks employees perform paid and unpaid overtime.

Hypothesis 3: Employees with a longer training period and employees with special training programmes or courses work paid or unpaid overtime more frequently than employees who had a short introduction on the job.

\section{Performance and Responsibility}

If the employees' performance is regularly assessed by their superiors, they have an incentive to offer unpaid overtime in order to get a better evaluation. In addition, paid overtime can be interpreted as a form of the employee's loyalty and motivation. This is even more true as paid overtime can be ordered by the employer, but employees - or their representatives - need not agree with it. ${ }^{1}$ According to the neoclassical theory of labour supply, employees in executive positions work overtime to compensate absent or less productive employees in order not to suffer a reputation loss. It also can be assumed that the time employees in executive positions need for a certain job cannot be assessed beforehand, and they often work unpaid overtime to cope with their workload. This argumentation can also be applied to employees with a higher level of autonomy in their workplace. Employees with a medium or a higher level of autonomy can decide more independently on the procedures and on how to carry out their tasks; the employer's control is mainly limited to the result. However, this also incurs the risk of working unpaid overtime, particularly, since the time that will be needed for a job can often not be predicted, but the employer is not interested in supervising the working hours.

Hypothesis 4: Employees with performance assessments by their superiors are more likely to work paid and unpaid overtime as compared to employees without performance assessments. Employees in executive positions or employees with a medium or higher level of autonomy have a higher probability of working unpaid overtime than employees in no executive positions or with a lower level of autonomy.

\section{Job Related Burdens}

Employees also face burdens in their job that they have to cope with. These burdens include the risk of losing their job, which might be caused by layoffs in the establishment or by limited employment contracts. According to the neoclassical theory of labour supply, a job at risk is associated with overtime work. Given a higher risk of unemployment, employees are more willing to work unpaid overtime in order to improve their own position in the establishment

\footnotetext{
${ }^{1}$ Paid overtime is regulated in collective agreements and company agreements, signed by employers and employees or their representatives.
} 
and thus to reduce the probability of a dissolution of their employment contract (Anger 2006b). Employees under limited employment contracts can supply paid or unpaid overtime work to signal their motivation and high willingness to work. Employers can appreciate this motivation and willingness and convert the limited contract into an unlimited employment contract.

Hypothesis 5: Employees with job related burdens due to a job at risk or a limited employment contract perform unpaid overtime work more often than employees without job related burdens or with an unlimited employment contract.

\section{Empirical Findings from Literature}

In the literature, there are already empirical findings about influencing factors of overtime work. Empirical results show that overtime first rises with the age of the employee, but then declines again (Gerlach/Hübler 1987; Bauer/Zimmermann 1999; Bell/Hart 1999b; Anger 2006b). Studies also find that blue-collar workers mainly do paid overtime, while white-collar workers mainly work unpaid overtime (Pannenberg/Wagner 2000, 2001; Anger 2005a). The qualification level, which can be operationalised by the school-leaving certificate, is positively correlated with the probability (and the amount) of (unpaid) overtime (Bauer/Zimmermann 1999; Pannenberg/Wagner 1999; Anger 2005b). Finally, the establishment size and the sector of industry also influence overtime work. The bigger the establishment is, the more decreases the probability for paid and unpaid overtime, although the coefficients are partly insignificant (Gerlach/Hübler 1987; Bell et al. 2000; Pannenberg/Wagner 2000) and also the public service is significantly correlated (Anger 2005b).

\section{Data, Variables and Methods}

\section{Data}

The data used in this study were made available by the German Socio Economic Panel Study (SOEP) ${ }^{2}$. The SOEP is an annual representative survey in private households and their members and started in West Germany in 1984 and in East Germany in 1990. The current life situation, employment, income, health and illness issues, as well as the family situation are central topics in the SOEP. Moreover, there are key issues that change every year, for example data on further education and qualification (Wagner/Frick/Schupp 2007; Göbel et al. 2008).

We use SOEP data from 2011 for male and female full-time and part-time employees aged between 18 and 65 in East and West Germany. Self-employed persons and family workers were dropped as well as all employees who were in an employment relationship, but who were not working at the time of the survey (e.g. employees on parental leave). Furthermore apprentices, persons in marginal employment (so called Minijobs) or Midijobs, conscripts,

2 Socio-Economic Panel (SOEP), data for years 1984-2012, version 29, SOEP, 2013, doi: 10.5684/soep.v29 
persons doing community service or voluntary social service were excluded. In total, the subsample consists of 5,168 people in the multivariate analyses (cf. Table 2).

The SOEP data from 2011 provide unique information about workplace specific factors, which were either not provided at all in other waves or only few factors were considered. Due to this, unfortunately a panel data set cannot be used in this study. However, it is presumed that these workplace-specific factors make an important contribution to the explanation of overtime work beyond the occupation and qualification level of employees, and so they will be in the focus of the further analyses.

\section{Dependent Variables}

As the basis for the dependent variables, two questions providing information about the incidence, amount and the compensation of overtime work were taken into consideration: (1) "If you do work overtime, is the work paid, compensated with time-off, or not compensated at all?" and (2) "How was your situation with regards to overtime last month? Did you work overtime? If yes, how many hours?" For the first question, the possible answers were "compensated with time-off", "partly paid, partly compensated with time-off", "paid" and "not compensated at all". The second question determines whether the survey respondents did work overtime hours and if so, how many hours they worked in the month preceding the survey. On this basis, the dependent variables Paid Overtime and Unpaid Overtime are coded as dummy variables (1/0) and consider a specific compensation form, which is in the focus of the following analyses. Paid Overtime takes the value of one if overtime work is usually paid and if in the month preceding the survey, overtime work was actually done. Unpaid Overtime takes the value of one if overtime work is usually not compensated at all and if in the month preceding the survey, overtime work was actually done. The dependent variables take the value of zero, if employees do not work overtime at all or did not work paid or unpaid overtime hours during the last month.

\section{Independent Variables}

As independent variables individual and also workplace-specific characteristics are taken into account. The individual factors include gender and employment status. For the workplacespecific characteristics, information about the extent of introduction on the job (short introduction on the job, longer training period in the establishment, special training or courses), performance assessments by a superior (yes, no), leadership position in the establishment (yes, no), occupational autonomy (low level, medium level, high level) and job related burdens due to a job at risk (yes, no) and a limited employment contract (yes, no) were included as explanatory variables.

\section{Control Variables}

The model also controls for variables for which empirical findings already exist in the literature, like age (under 30 years, 30 to 49 years, 50 years and older), the qualification (secondary general school, intermediate school, upper secondary school), occupational 
status (blue-collar workers, white-collar workers, civil servant) and the years of employment in the establishment. Moreover, the industrial relations are taken into account including whether a works council exists in the establishment (yes, no), whether the person interviewed is member of this works council (yes, no) and/or is a member of a trade union (yes, no). The model also controls for establishment size (less than 20 employees, 20 to 199 employees, 200 to 1999 employees, more than 2000 employees), industry (manufacturing industry incl. construction, commerce/transport and catering industry, other services, public service/education/health) and region (West Germany, East Germany).

\section{Method}

In the multivariate analyses, the probability of employees working paid or unpaid overtime is attributed to the individual and workplace-specific characteristics by using probit models. However, it has to be said that with the present probit models it is not possible to make a causal interpretation for overtime work. The estimations are based on two models. There is a model covering only paid overtime and a model covering only unpaid overtime. As a robustness test tobit models were estimated with the number of paid or unpaid overtime hours.

\section{Incidence and Determinants of Overtime Work}

The long-term development concerning the compensation form of overtime work shows that the compensation with time-off gained in importance between 1991 and 2011, while paid overtime declined (Figure 1). ${ }^{3}$ The percentage of employees that are usually paid for overtime work declined from about 35 to 11 per cent, while the percentage of a compensation with time-off has increased from 35 to 50 per cent. Every second employee can take time off in lieu of overtime worked at a later point in time. ${ }^{4}$ The number of persons who do not receive any compensation for overtime increased slightly during the period under review (15.2\% in 1991 and $18.3 \%$ in 2011).

The importance of compensation with time-off can be explained by the increasing number of working time accounts in establishments which can manage and control this transitory overtime work (Ellguth/Gerner/Zapf 2013).

Although transitory overtime hours gained in importance the following analyses focus on paid and unpaid overtime work. Paid and unpaid overtime hours extend the working time of employees, whereas transitory overtime hours (normally) only distribute the working time of employees over a certain period of time in another way.

\footnotetext{
${ }^{3}$ The results refer to both West and East Germany. There are hardly any differences in the year 1991 when taking only West Germany into account.

${ }^{4}$ However, transitory overtime can also become paid overtime hours when employees are not able to take time-off and therefore establishments offer a financial compensation. Transitory overtime hours can also become unpaid hours if they cannot be compensated by time-off in a specified period of time and are therefore cut.
} 


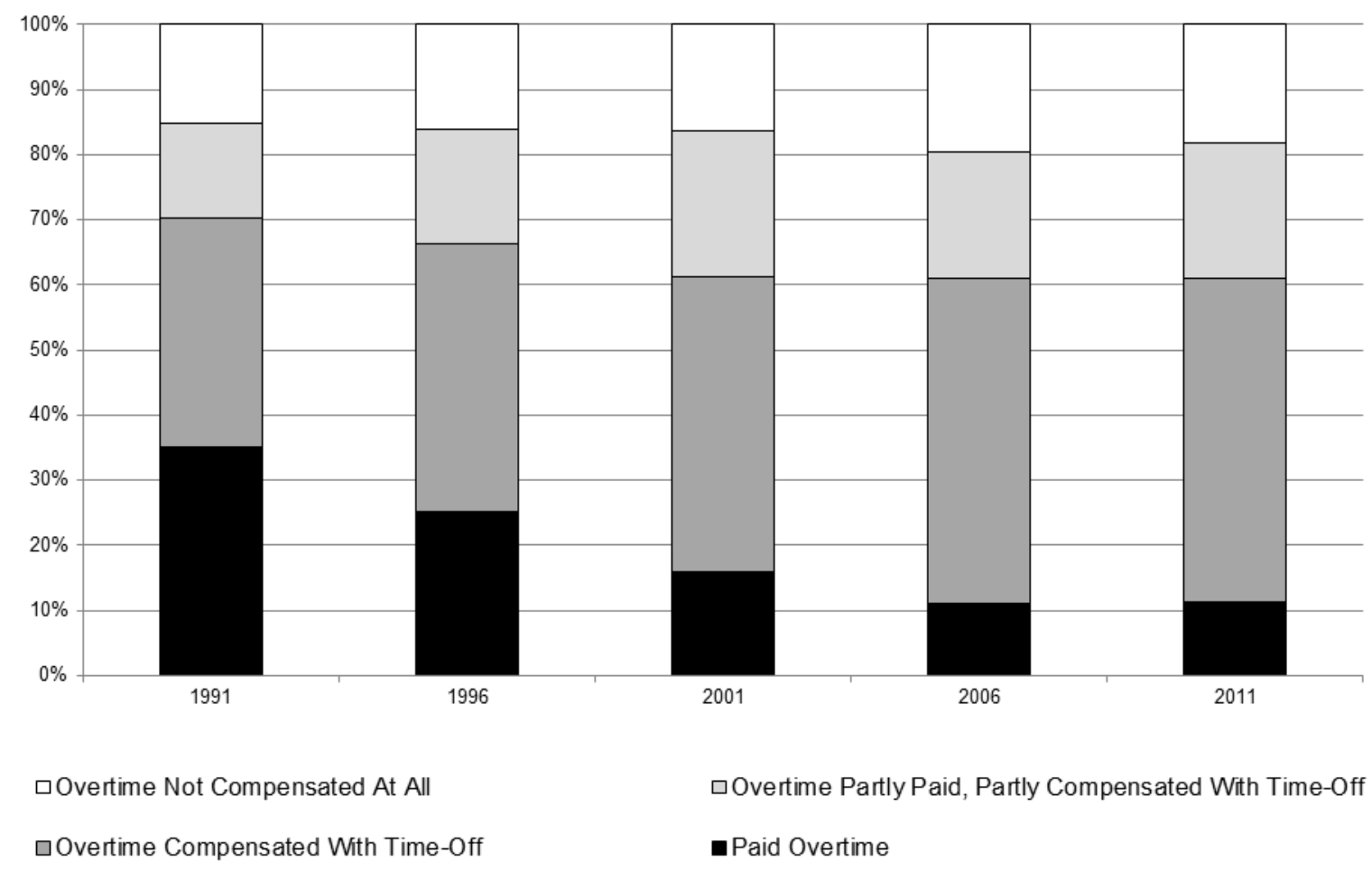

Source: SOEP 1991-2011, weighted results, illustration by the author.

\subsection{Descriptive Findings}

In 2011, more men than women worked overtime hours (59.4\% as compared to $54.6 \%$ ), and among overtime workers the percentage of men who had worked paid or unpaid overtime was higher than the corresponding share of women (cf. Table 1). The percentage of employees who worked overtime is also higher in the group of full-time employees than in the group of part-time employees (59.4\% as compared to $49.0 \%$ ), and full-time employees with overtime hours do not receive any financial compensation at all more often than parttime employees. Furthermore, the percentage of employees who work overtime increases with the extent of introduction on the job in the establishment. Employees with a longer training period and employees who attended special training programmes or courses work overtime more frequently ( $59.4 \%$ and $64.4 \%$, respectively) than employees with only a short introduction on the job (44.0\%). With a longer introduction on the job, the importance of unpaid overtime increases, while the share of paid overtime decreases. Among employees with overtime and a short introduction on the job, around 22 per cent got paid for the overtime hours worked, while only 8 per cent of the employees who attended training programmes or courses got paid for the overtime work. Employees who are subject to performance evaluations by their superiors work overtime more often than employees without such an evaluation (66.0 \% as opposed to $53.5 \%$ ). This is also true for employees 
with or without executive positions (70.9\% and $53.3 \%)$. Among overtime workers, the percentage of employees working unpaid overtime is higher in the group of employees who are subject to performance evaluations or have an executive position than in the reference group. For employees who work paid overtime, the relation is reversed. An increasing autonomy also leads to an increase in overtime work, with paid overtime losing more and more of its importance, while unpaid overtime gets more important. Employees who suffer from job related burdens because their job is at risk do not work overtime as often as the reference group ( $49.9 \%$ as compared to $58.5 \%$ ). Here the percentage of paid overtime is higher, while overtime not compensated at all is lower as compared to the reference group. There are hardly any differences between employees under limited or unlimited employment contracts. What is striking, however, is the fact that employees under a limited contract get paid for their overtime work more often, and that employees with unlimited contracts do not get any compensation more frequently. This might indicate a selection effect according to which employees with an unlimited employment contract received such a contract because they had worked more unpaid overtime hours in the past.

As far as age, occupational status and school education are concerned, the descriptive findings confirm the empirical results in the literature. Concerning the sector of industry overtime is still less common in the sector commerce, transport and catering industry than in the sector public services, education and health. But the percentage of paid and unpaid overtime is smallest in the sector of public service, education and health. With the establishment size, the percentage of overtime first increases, but it is paid or not compensated at all to a smaller extent. Overtime work is also done more frequently in establishments with a works council (60.0\%), paid and unpaid overtime playing a minor role. However, members of a trade union do not work as much overtime as employees without membership ( $55.1 \%$ as compared to $57.2 \%$ ), but paid and unpaid overtime also play a less important role here. 
Table 1: Incidence of overtime, 2011

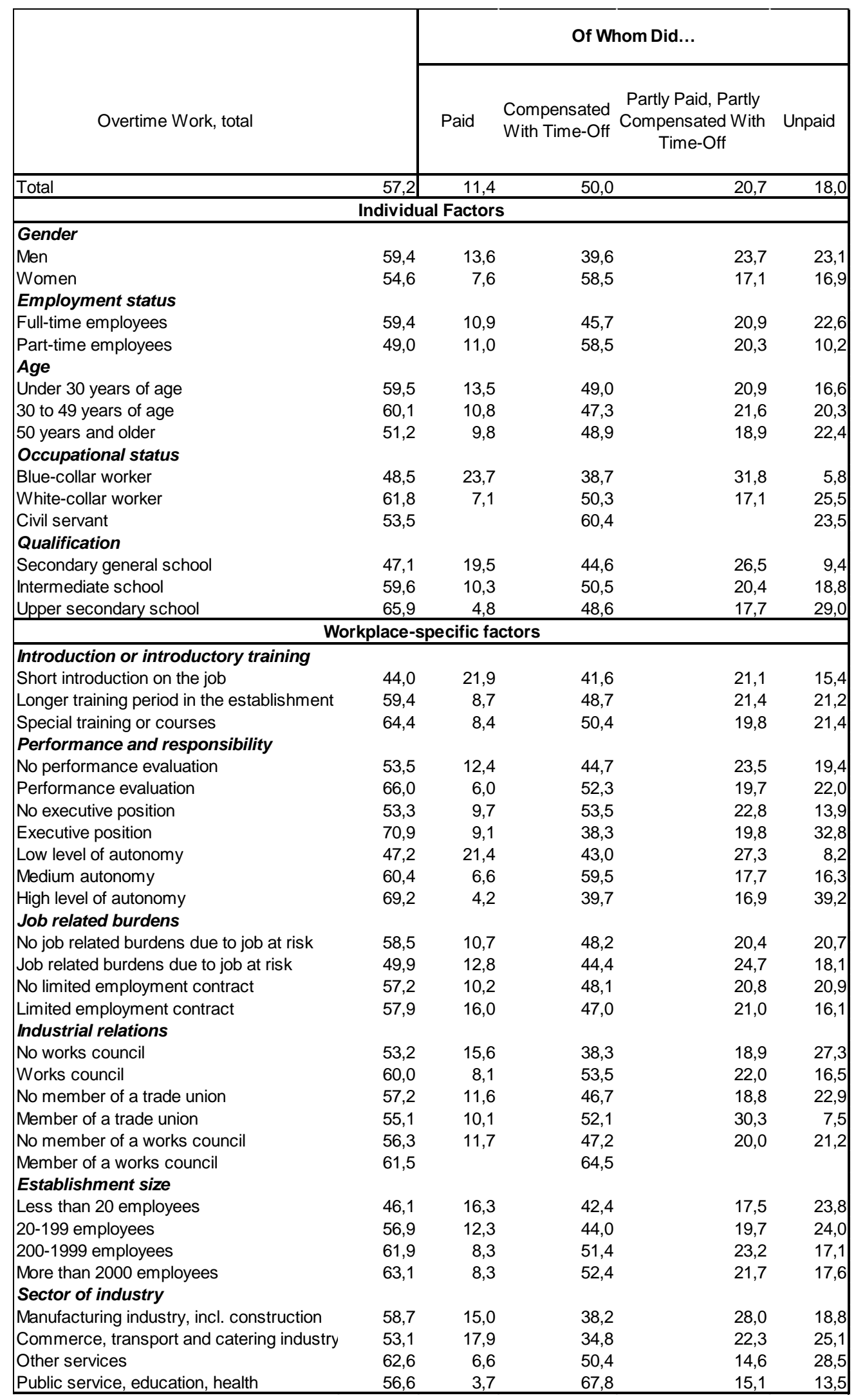

Source: SOEP 2011, weighted results, calculations by the author. Sample includes all full-time and part-time employees between 18 and 65 years.

Note: Some cells are not occupied if the numbers of cases were not sufficient. $(n<50)$ 


\subsection{Multivariate Analyses}

\section{Paid Overtime}

For paid overtime the assumed negative association with gender can be shown $(p<0.01)$ with men working paid overtime more frequently than women (cf. Table 2). On average, the probability of women to work paid overtime is around 4 percentage points less high than for men. The multivariate analyses therefore confirm the descriptive findings that exist in the literature concerning the gender-specific differences in overtime work (cf. Bell et al. 2000; Anger 2006b; Brautzsch/Drechsel/Schultz 2012). The employment status shows a positive association on the ten per cent level. Paid overtime work could be more attractive to parttime workers in order to increase their regular wage. The extent of the introduction on the job is not significant, whereas the results show a significant negative association for employees being subject to performance evaluations. However, for employees in executive positions, the probability of paid overtime increases $(p<0.01)$, while it declines with an increasing autonomy $(p<0.01$ each). If employees consider their job at risk, the probability of working paid overtime also decreases, although it is not significant. In contrast, a limited employment contract is positively correlated with paid overtime $(p<0.1)$.

\section{Unpaid Overtime}

In contrast to paid overtime, the gender effect for unpaid overtime is also negative but no longer significant (cf. Table 2). In the present estimation model, the descriptive findings from the literature concerning unpaid overtime (cf. Bell et al. 2000; Brautzsch/Drechsel/Schultz 2012) cannot be confirmed. However, the employment status shows a significant negative association $(p<0.01)$. On average, the probability to work unpaid overtime is around 7 percentage points lower for part-time employees than for full-time employees. On the one hand, this finding seems to indicate that part-time employees already attain the maximum benefit with their regular working hours and therefore work less unpaid overtime. On the other hand, part-time workers can also have time constraints due to family obligations and work therefore less unpaid overtime hours. The results also support the thesis that less investment in human capital is incurred for part-time employees. With an increasing introduction on the job there is a negative impact on the probability of unpaid overtime work, but it is not significant. On the basis of this result, the assumption that after a longer introduction on the job, human capital is procured subsequently in the context of unpaid overtime, cannot be confirmed. However, a positive correlation with unpaid overtime can be observed for employees subject to performance evaluations or in executive positions $(p<0.1$ and $p<0.01$ ) and also employees with a higher autonomy have a higher probability for working unpaid overtime ( $p<0.01$ each). Employees with a high autonomy have on average an about 13 percentage points higher probability of working unpaid overtime than employees with a low level of autonomy. Job related burdens due to a job at risk increases the probability of unpaid overtime work, but it is not significant. This is in line with Anger (2006a), who states that a higher perceived risk of unemployment does not have any significant effect on unpaid overtime work. For employees under limited employment contracts, there is a 
negative but not significant correlation - in contrast to paid overtime. This could be interpreted in such a way that employees under limited contracts do not have a perspective for an unlimited contract with their employer, and are therefore not willing to supply unpaid overtime work.

Table 2: Individual and workplace-specific determinants of overtime work, 2011

\begin{tabular}{|c|c|c|c|c|c|c|}
\hline & & aid Overtim & & Unpa & iid Overtime & \\
\hline & Coef. & Std. Error & $\begin{array}{l}\text { Average } \\
\text { Marginal } \\
\text { Effects }\end{array}$ & Coef. & Std. Error & $\begin{array}{l}\text { Average } \\
\text { Marginal } \\
\text { Effects }\end{array}$ \\
\hline $\begin{array}{l}\text { Gender } \\
\text { Female (1=yes) }\end{array}$ & $-0,383^{* * *}$ & 0,085 & $-0,035$ & $-0,063$ & 0,057 & $-0,010$ \\
\hline Employment Status & & & & & & \\
\hline $\begin{array}{l}\text { Part-time (1=yes) } \\
\text { Required introduction or introductory training: } \\
\text { Ref. cat. short introduction on the job }\end{array}$ & 0,163 * & 0,099 & 0,015 & $-0,390 * * *$ & 0,077 & $-0,065$ \\
\hline Longer training period in the estabslishment ( $1=y e s)$ & $-0,052$ & 0,084 & $-0,005$ & $-0,112$ & 0,075 & $-0,019$ \\
\hline $\begin{array}{l}\text { Special training or courses ( } 1=y e s) \\
\text { Performance evaluation }\end{array}$ & 0,008 & 0,098 & 0,001 & $-0,067$ & 0,080 & $-0,011$ \\
\hline $\begin{array}{l}\text { Performance evaluation by a superior ( } 1=y e s) \\
\text { Executive position }\end{array}$ & $-0,285 * * *$ & 0,080 & $-0,026$ & 0,099 * & 0,058 & 0,017 \\
\hline $\begin{array}{l}\text { Executive position (1=yes) } \\
\text { Autonomy at the workplace: Ref. cat. low level o } \\
\text { autonomy }\end{array}$ & $0,297^{* * *}$ & 0,080 & 0,027 & $0,308 * \star *$ & 0,058 & 0,051 \\
\hline Medium autonomy ( $1=$ yes) & $-0,254 * * *$ & 0,097 & $-0,023$ & $0,245^{* * *}$ & 0,089 & 0,041 \\
\hline $\begin{array}{l}\text { High level of autonomy (1=yes) } \\
\text { Job related burdens }\end{array}$ & $-0,364^{* * *}$ & 0,124 & $-0,033$ & $0,779 * * *$ & 0,095 & 0,130 \\
\hline $\begin{array}{l}\text { Job related burdens due to job at risk ( } 1=y e s) \\
\text { Limited employment contract }\end{array}$ & $-0,174$ & 0,111 & $-0,016$ & 0,065 & 0,080 & 0,011 \\
\hline $\begin{array}{l}\text { Limited employment contract }(1=y e s) \\
\text { Age: } \text { Ref. cat. under } 30 \text { years of age }\end{array}$ & 0,206 * & 0,116 & 0,019 & $-0,084$ & 0,104 & $-0,014$ \\
\hline 30 to 49 years $(1$ & 0,118 & 0,108 & 0,011 & $-0,093$ & 0,088 & $-0,016$ \\
\hline 50 years and older ( $1=$ yes $)$ & 0,164 & 0,124 & 0,015 & 0,139 & 0,094 & 0,023 \\
\hline $\begin{array}{l}\text { Qualification: Ref. cat. secondary general school } \\
\text { Intermediate school ( } 1=y e s)\end{array}$ & 0,098 & 0,081 & 0,009 & $0,314 * * *$ & 0,082 & 0,052 \\
\hline $\begin{array}{l}\text { Upper secondary school ( } 1=\text { yes }) \\
\text { Occupational status: Ref. cat. blue-collar worker }\end{array}$ & $-0,055$ & 0,103 & $-0,005$ & $0,417^{* * *}$ & 0,076 & 0,070 \\
\hline White-collar worker ( $1=$ yes) & $-0,150$ & 0,094 & $-0,014$ & $0,496 * \star *$ & 0,095 & 0,083 \\
\hline $\begin{array}{l}\text { Civil servant }(1=y e s) \\
\text { Years of employment in the establishment }\end{array}$ & $-0,484^{* *}$ & 0,238 & $-0,044$ & $0,614 * * *$ & 0,145 & 0,103 \\
\hline $\begin{array}{l}\text { Years of employment in the establishment } \\
\text { Industrial relations }\end{array}$ & $-0,011^{* * *}$ & 0,004 & $-0,001$ & $-0,004$ & 0,003 & $-0,001$ \\
\hline Existence of a works council ( $1=y e s)$ & $-0,194$ ** & 0,092 & $-0,018$ & $-0,416$ *** & 0,075 & $-0,069$ \\
\hline Member of a trade $\iota$ & $-0,001$ & 0,099 & 0,000 & $-0,454^{* * *}$ & 0,095 & $-0,076$ \\
\hline $\begin{array}{l}\text { Member of a works council ( } 1=y e s) \\
\text { Establishment size: Ref. cat. less than } 20 \\
\text { employees }\end{array}$ & $-0,111$ & 0,215 & $-0,010$ & 0,025 & 0,147 & 0,004 \\
\hline 20 to 199 employees ( $1=y e s$ ) & 0,080 & 0,091 & 0,007 & $0,210 * * *$ & 0,076 & 0,035 \\
\hline 200 to 1999 employees ( $1=y e s$ ) & 0,123 & 0,118 & 0,011 & $-0,032$ & 0,097 & $-0,005$ \\
\hline $\begin{array}{l}\text { More than } 2000 \text { employees ( } 1=y e s) \\
\text { Sector of industry: Ref. cat. manufacturing } \\
\text { industry, incl. construction }\end{array}$ & 0,224 * & 0,131 & 0,020 & 0,012 & 0,104 & 0,002 \\
\hline Commerce, transport and catering industry ( $1=y e s)$ & 0,040 & 0,082 & 0,004 & $0,269 * * *$ & 0,080 & 0,045 \\
\hline Other services (1=yes) & $-0,229 * *$ & 0,103 & $-0,021$ & 0,074 & 0,071 & 0,012 \\
\hline $\begin{array}{l}\text { Public service, education, health (1=yes) } \\
\text { Region }\end{array}$ & $-0,156$ & 0,109 & $-0,014$ & $-0,352$ *** & 0,086 & $-0,059$ \\
\hline East Germany (1=yes) & $-0,123$ & 0,080 & $-0,011$ & 0,015 & 0,065 & 0,002 \\
\hline Constant & $-1,197^{\star * \star}$ & 0,140 & & $-1,943^{\star \star \star}$ & 0,138 & \\
\hline
\end{tabular}

${ }^{*} \mathrm{p}<0.1 ;{ }^{* *} \mathrm{p}<0.05 ;{ }^{* * *} \mathrm{p}<0.01$

Source: SOEP 2011, calculations by the author. Sample includes all full-time and part-time employees between 18 and 65 years. 
In the appendix, the models were estimated separately for full-time and part-time employees. There are hardly any differences between the model including all employees and the model with only full-time employees.

\section{Conclusion}

The aim of the study was to analyse workplace-specific factors and their contribution to explain the incidence of paid and unpaid overtime work. In other studies, these factors have not been considered enough, mainly due to the limited data. However, the 2011 data of the SOEP includes unique information about workplace-specific factors.

In the analyses women and part-time employees, who have a different labour market behaviour than men and full-time employees, were integrated too, due to their growing importance on the labour market. The estimations were made for the so-called definitive paid and unpaid overtime work. It is true that transitory overtime hours have gained much in importance, but they only lead to another distribution of working hours and not to longer working hours. Employees might well be interested in transitory overtime work, for example to combine work and family more easily, but it is mainly the establishments that decide whether transitory overtime hours are worked or not.

The empirical results about the determinants of overtime work are ambivalent and therefore, the hypotheses set forth in chapter 3 can be confirmed empirically only in part. As to gender, the correlation shows the assumed negative direction, but it is only significant negative for paid overtime. Therefore, women have a lower probability of increasing their income by paid overtime, while this is more often the case for men. However, due to the non-significant effect on unpaid overtime, the assumption of fewer human capital investments and fewer chances of promotions or pay rises due to unpaid overtime among women is not confirmed here. Hypotheses 1 can be confirmed only in part.

For the employment status, there is a significant positive association with paid overtime and a negative association with unpaid overtime. It can be assumed that part-time employees work paid overtime in order to increase their regular wage. However, due to the negative association with unpaid overtime it can be assumed that part-time employees are less inclined to invest in human capital by working longer. Thus, hypotheses 2 can also be confirmed only in part.

The third hypothesis concerning the introduction on the job cannot be confirmed for paid and unpaid overtime. The results cannot confirm that employees with a longer training period or participating in special training or courses invest more in human capital or procure more human capital than employees with a short introduction. The introduction on the job rather seems to have no influence on future human capital investments by paid and unpaid overtime.

Performance evaluations by superiors are negatively associated with paid overtime and positively associated with unpaid overtime. By providing unpaid overtime employees can 
signal a high value of their work to their employer. The positive correlation between an executive position and overtime is confirmed in the two estimations. The probability of unpaid overtime work increases with an increasing autonomy, but it decreases for paid overtime. All in all, the assumption that with an increasing autonomy, unpaid overtime is used more often to cope with the workload was supported. But altogether, hypotheses 4 can be confirmed in part.

Finally, overtime work is not associated with job related burdens due to a risk of losing the job, and a limited employment contract seems to have only little effect on paid but not on unpaid overtime. Hypotheses 5 can be confirmed only in part.

To summarise, it can be stated that paid overtime is done more often by part-time employees and employees with a limited employment contract. Surprisingly, employees in executive positions also have a higher probability to work paid overtime. In contrast, unpaid overtime is done by employees subject to performance evaluations, in executive positions and with a higher autonomy in their workplace. Therefore, the demands of reducing unpaid overtime hours in order to improve the situation on the labour market and to create more jobs are hardly feasible. Unpaid overtime work is mainly supplied by employees with a higher qualification, which makes a redistribution of overtime hours on more employees difficult due to the specific qualification profile required. On average, unemployed people have a lower qualification level. Furthermore, transitory overtime has gained in importance, which is considered as having a neutral effect on employment as opposed to unpaid overtime work (Zapf 2012). 


\section{References}

Akerlof, George A. (1984): Gift Exchange and Efficiency-Wage Theory. Four Views. In: The American Economic Review, Vol. 74, Issue 2, S. 79-83.

Akerlof, George A. (1982): Labor Contracts as Partial Gift Exchange. In: The Quarterly Journal of Economics, Vol. 97, No. 4, S. 543-569.

Anger, Silke (2008): Overtime Work as a Signaling Device. In: Scottish Journal of Political Economy, Vol. 55, No. 2, S. 167-189.

Anger, Silke (2006a): Overtime Work in Germany. The Investment Character of Unpaid Hours, Aachen: Shaker Verlag.

Anger, Silke (2006b): Zur Vergütung von Überstunden in Deutschland: Unbezahlte Mehrarbeit auf dem Vormarsch. DIW-Wochenbericht Jg. 73, Nr. 15-16, S. 189-196.

Anger, Silke (2005a): Working Time as an Investment? The Effects of Unpaid Overtime on Wages, Promotions, and Layoffs. DIW Discussion Papers No. 535.

Anger, Silke (2005b): Unpaid Overtime in Germany. Differences between East and West. In: Schmollers Jahrbuch 125, S. 17-27.

Bauer, Frank; Groß, Hermann; Lehmann, Claudia; Munz, Eva (2004): Arbeitszeit 2003. Arbeitszeitgestaltung, Arbeitsorganisation und Tätigkeitsprofile. Köln.

Bauer, Frank; Groß, Hermann; Munz, Eva; Sayin, Suna (2002): Arbeits- und Betriebszeiten 2001. Neue Formen des betrieblichen Arbeits- und Betriebszeitmanagements. Ergebnisse einer repräsentativen Betriebsbefragung. Köln.

Bauer, Thomas; Zimmermann, Klaus F. (1999): Overtime Work and Overtime Compensation in Germany. In: Scottish Journal of Political Economy, Vol. 46, No. 4, S. 419-439.

Becker, Gary S. (1962): Investment in Human Capital. A Theoretical Analysis. In: The Journal of Political Economy, Vol. 70, Issue 5 Part 2, S. 9-49.

Behnke, Cornelia; Meuser, Michael (2005): Vereinbarkeitsmanagement. Zuständigkeiten und Karrierechancen bei Doppelkarrierepaaren. In: Solga, Heike; Wimbauer, Christine (Hrsg.) (2005): Wenn zwei das Gleiche tun...Ideal und Realität sozialer (Un-)Gleichheit in Dual Career Couples. Leverkusen: Budrich, S. 123-139.

Bell, David N.F.; Hart, Robert A. (1999a): Unpaid Work. In: Economica, 66, S. 271-290.

Bell, David N.F.; Hart, Robert A. (1999b): Overtime Working in an Unregulated Labour Market. IZA Discussion Paper, No. 44.

Bell, David N.F.; Hart, Robert A.; Hübler, Olaf; Schwerdt, Wolfgang (2000): Paid and Unpaid Overtime Working in Germany and the UK. IZA Discussion Paper No. 133. 
Bell, Linda A.; Freeman, Richard B. (2001): The incentive for working hard. explaining hours worked differences in the US and Germany. In: Labour Economics, 8, S. 181-202.

Bellmann, Lutz; Gewiese, Tilo (2003): Betriebliche Arbeitszeitstrukturen in der Bundesrepublik Deutschland. Empirische Ergebnisse aus dem IAB-Betriebspanel 1996-1999 unter besonderer Berücksichtigung der Arbeitszeitflexibilisierung. Schriftenreihe der Bundesanstalt für Arbeitsschutz und Arbeitsmedizin. Forschung Fb 1007. Dortmund/Berlin/Dresden.

Bispinck, Reinhard (2005): Immer flexibler - und immer länger? Tarifliche Regelungen zur Arbeitszeit und ihrer Gestaltung. Eine Analyse von 24 Tarifbereichen. Informationen zur Tarifpolitik Nr. 57. Düsseldorf.

Brautzsch, Hans-Ulrich; Drechsel, Katja; Schultz, Birgit (2012): Unbezahlte Überstunden in Deutschland. In: Wirtschaft im Wandel, 18 (10), S. 308-315.

Bundesmann-Jansen, Jörg; Groß, Hermann; Munz, Eva (2000): Arbeitszeit '99. Ergebnisse einer repräsentativen Beschäftigtenbefragung zu traditionellen und neuen Arbeitszeitformen in der Bundesrepublik Deutschland. Köln.

Ellguth, Peter; Gerner, Hans-Dieter; Zapf, Ines (2013): Flexibilität für Betriebe und Beschäftigte. Vielfalt und Dynamik bei den Arbeitszeitkonten. IAB-Kurzbericht 3. Nürnberg.

Fuchs, Johann; Hummel, Markus; Hutter, Christian; Klinger, Sabine; Wanger, Susanne; Weber, Enzo; Weigand, Roland; Zika, Gerd (2013): IAB-Prognose 2013/2014. Arbeitslosigkeit sinkt trotz Beschäftigungsrekord nur wenig. IAB-Kurzbericht 18. Nürnberg.

Gerlach, Knut; Hübler, Olaf (1987): Personalnebenkosten, Beschäftigtenzahl und Arbeitsstunden aus neoklassischer und institutionalistischer Sicht. In: Buttler, Friedrich; Gerlach, Knut; Schmiede, Rudi (Hrsg.) (1987): Arbeitsmarkt und Beschäftigung. Neuere Beiträge zur institutionalistischen Arbeitsmarktanalyse. Frankfurt/New York: Campus Verlag, S. 291-325.

Göbel, Jan; Krause, Peter; Pischner, Rainer; Sieber, Ingo; Wagner, Gert G. (2008): Daten und Datenbankstruktur der Längsschnittstudie Sozio-oekonomisches Panel (SOEP). SOEPpapers on Multidisciplinary Panel Data Research 89.

Gold, Michael (2004): Anpassungskosten: eine Ursache für Überstunden. Eine empirische Untersuchung mit deutschen Betriebsdatensätzen. In: Wirtschaft und Statistik, Heft 2, S. 234-242.

Gold, Michael (2002): Mikroökonomische Analyse der Arbeitsnachfrage. Eine Untersuchung von Beschäftigungsdynamik und Überstundennachfrage unter dem Einfluss von Anpassungskosten mit deutschen Betriebsdatensätzen. Hamburg: Verlag Dr. Kovac. 
Hunt, Jennifer (2012): Flexible Work Time in Germany: Do Workers Like It and How Have Employers Exploited It Over the Cycle? SOEPpapers on Multidisciplinary Panel Data Research 489.

Keller, Berndt; Seifert, Hartmut (2006): Atypische Beschäftigungsverhältnisse: Flexibilität, soziale Sicherheit und Prekarität. WSI-Mitteilungen, Jg. 59, Heft 5, S. 235-240.

Koch, Susanne (2001): Arbeitszeit und Arbeitsvolumen - Teil II: Arbeitszeitkonten stabilisieren die Beschäftigung. IAB-Kurzbericht Nr. 4. Nürnberg.

Lazear, Edward P. (1979): Why Is There Mandatory Retirement? In: Journal of Political Economy, Vol. 87, No. 6, S. 1261-1284.

Lazear, Edward P.; Rosen, Sherwin (1981): Rank-Order Tournaments as Optimum Labor Contracts. In: Journal of Political Economy, Vol. 89, No. 5, S. 841-864.

Pannenberg, Markus; Wagner, Gert G. (2000). Umfang und Kompensation von Überstunden. Eine vergleichende Analyse für Westdeutschland und Großbritannien. DIW Discussion Paper No. 234.

Pannenberg, Markus und Wagner, Gert G. (2001): Overtime Work, Overtime Compensation and the Distribution of Economic Well-Being. Evidence for West Germany and Great Britain. Discussion Paper No. 318.

Pannenberg, Markus (2005): Long-Term Effects Of Unpaid Overtime. Evidence for West Germany. In: Scottish Journal of Political Economy, Vol. 52, No. 2, S. 177-193.

Prendergast, Canice (1999): The Provision of Incentives in Firms. In: Journal of Economic Literature, Vol. 37, No.1, S. 7-63.

Schank, Thorsten; Schnabel, Claus (2004). Betriebliche Determinanten des Überstundeneinsatzes. Discussion Papers No. 24.

Shapiro, Carl; Stiglitz, Joseph E. (1984): Equilibrium Unemployment as a Worker Discipline Device. In: The American Economic Review, Vol. 74, No. 3, S. 433-444.

Spence, Michael (1973): Job Market Signaling. In: The Quarterly Journal of Economics, Vol. 87 , No. 3, S. 355-374.

Taris, Toon W.; Ybema, Jan Fekke; Beckers Debby G.J.; Verheijden, Marieke W.; Geurts, Sabine A.E.; Kompier, Michael A.J. (2011): Investigating the Associations among Overtime Work, Health Behaviors, and Health. A longitudinal Study among Full-time Employees. In: International Journal of Behavioral Medicine. Vol. 18, Issue 4, S. 352-360. 
Van der Hulst, Monique; Geurts, Sabine (2001): Associations between overtime and psychological health in high and low reward jobs. In: Work \& Stress: An International Journal of Work, Health \& Organisations. Vol. 15, Issue 3, S. 227-240.

Wagner, Gert G.; Frick, Joachim R.; Schupp, Jürgen (2007): The German Socio-Economic Panel Study (SOEP). Scope, Evolution and Enhancements. In: Schmollers Jahrbuch 127, Heft 1, S. 139-169.

Zapf, Ines (2012): Flexibilität am Arbeitsmarkt durch Überstunden und Arbeitszeitkonten. Messkonzepte, Datenquellen und Ergebnisse im Kontext der IAB-Arbeitszeitrechnung. IABForschungsbericht 3. Nürnberg. 


\section{Appendix}

Table 3: Individual and workplace-specific determinants of paid overtime work, 2011

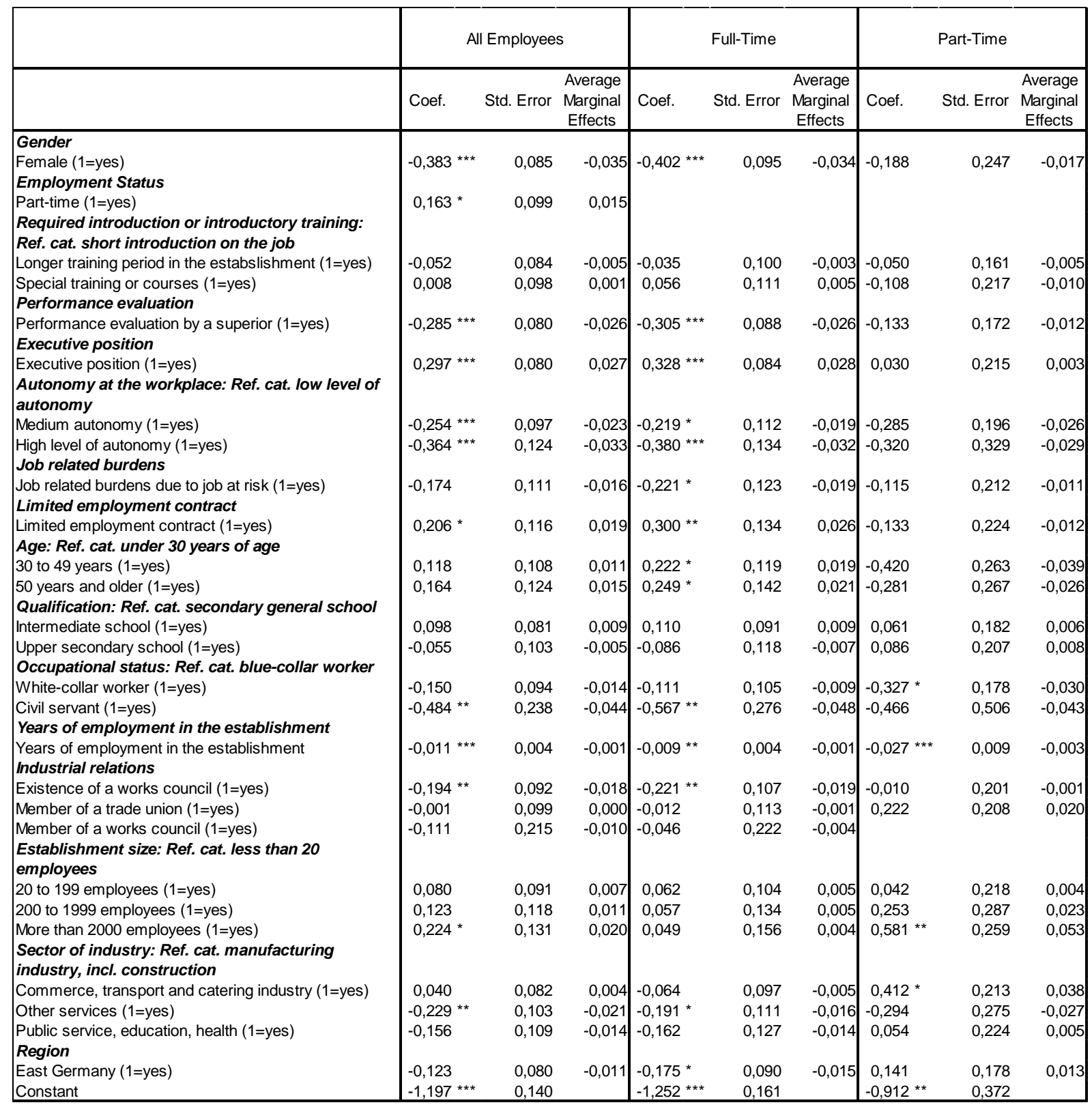

${ }^{*} p<0.1 ;{ }^{* *} p<0.05 ;{ }^{* * *} p<0.01$

Source: SOEP 2011, calculations by the author. Sample includes employees between 18 and 65 years. 
Table 4: Individual and workplace-specific determinants of unpaid overtime work, 2011

\begin{tabular}{|c|c|c|c|c|c|c|c|c|c|}
\hline & \multicolumn{3}{|c|}{ All Employees } & \multicolumn{3}{|c|}{ Full-Time } & \multicolumn{3}{|c|}{ Part-Time } \\
\hline & Coef. & Std. Error & $\begin{array}{l}\text { Average } \\
\text { Marginal } \\
\text { Effects }\end{array}$ & Coef. & Std. Error & $\begin{array}{l}\text { Average } \\
\text { Marginal } \\
\text { Effects }\end{array}$ & Coef. & Std. Error & $\begin{array}{c}\text { Average } \\
\text { Marginal } \\
\text { Effects }\end{array}$ \\
\hline Gender & & & & & & & & & \\
\hline $\begin{array}{l}\text { Female (1=yes) } \\
\text { Employment Status }\end{array}$ & $-0,063$ & 0,057 & $-0,010$ & $-0,085$ & 0,060 & $-0,015$ & 0,414 & 0,319 & 0,037 \\
\hline $\begin{array}{l}\text { Part-time ( } 1=y e s) \\
\text { Required introduction or introductory training: } \\
\text { Ref. cat. short introduction on the job }\end{array}$ & $-0,390 * * *$ & 0,077 & $-0,065$ & & & & & & \\
\hline Longer training period in the estabslishment ( $1=y e s)$ & $-0,112$ & 0,075 & $-0,019$ & $-0,068$ & 0,089 & $-0,012$ & $-0,330 *$ & 0,187 & $-0,029$ \\
\hline $\begin{array}{l}\text { Special training or courses ( } 1=y e s) \\
\text { Performance evaluation }\end{array}$ & $-0,067$ & 0,080 & $-0,011$ & $-0,022$ & 0,096 & $-0,004$ & $-0,282$ & 0,198 & $-0,025$ \\
\hline $\begin{array}{l}\text { Performance evaluation by a superior ( } 1=\mathrm{yes}) \\
\text { Executive position }\end{array}$ & 0,099 * & 0,058 & 0,017 & 0,125 ** & 0,061 & 0,022 & $-0,036$ & 0,164 & $-0,003$ \\
\hline $\begin{array}{l}\text { Executive position (1=yes) } \\
\text { Autonomy at the workplace: Ref. cat. low level of } \\
\text { autonomy }\end{array}$ & $0,308^{* * *}$ & 0,058 & 0,051 & $0,328^{* * *}$ & 0,067 & 0,058 & 0,298 * & 0,179 & 0,026 \\
\hline Medium autonomy ( $1=$ yes) & $0,245 * * *$ & 0,089 & 0,041 & 0,183 * & 0,099 & 0,032 & 0,368 * & 0,214 & 0,033 \\
\hline $\begin{array}{l}\text { High level of autonomy ( } 1=y e s) \\
\text { Job related burdens }\end{array}$ & $0,779 * * *$ & 0,095 & 0,130 & $0,728^{* * *}$ & 0,109 & 0,129 & $0,813^{* * *}$ & 0,273 & 0,072 \\
\hline $\begin{array}{l}\text { Job related burdens due to job at risk ( } 1=\mathrm{yes}) \\
\text { Limited employment contract }\end{array}$ & 0,065 & 0,080 & 0,011 & 0,101 & 0,090 & 0,018 & $-0,029$ & 0,185 & $-0,003$ \\
\hline $\begin{array}{l}\text { Limited employment contract }(1=y e s) \\
\text { Age: } \text { Ref. cat. under } 30 \text { years of age }\end{array}$ & $-0,084$ & 0,104 & $-0,014$ & $-0,013$ & 0,115 & $-0,002$ & $-0,544$ * & 0,285 & $-0,048$ \\
\hline 30 to 49 years ( $1=$ yes $)$ & $-0,093$ & 0,088 & $-0,016$ & $-0,091$ & 0,094 & $-0,016$ & $-0,169$ & 0,354 & $-0,015$ \\
\hline 50 years and older $(1=$ yes $)$ & 0,139 & 0,094 & 0,023 & 0,102 & 0,100 & 0,018 & 0,232 & 0,373 & 0,021 \\
\hline Qualification: Ref. cat. secondary general school & & & & & & & & & \\
\hline Intermediate school (1=yes) & $0,314^{* * *}$ & 0,082 & 0,052 & $0,321^{* \star *}$ & 0,087 & 0,057 & 0,306 & 0,248 & 0,027 \\
\hline $\begin{array}{l}\text { Upper secondary school ( } 1=y e s) \\
\text { Occupational status: Ref. cat. blue-collar worker }\end{array}$ & $0,417^{* * *}$ & 0,076 & 0,070 & $0,432^{* * *}$ & 0,085 & 0,077 & 0,413 & 0,254 & 0,036 \\
\hline White-collar worker ( $1=$ yes $)$ & $0,496 * * *$ & 0,095 & 0,083 & $0,610 * * *$ & 0,100 & 0,108 & 0,070 & 0,270 & 0,006 \\
\hline $\begin{array}{l}\text { Civil servant ( } 1=y e s) \\
\text { Years of employment in the establishment }\end{array}$ & 0,614 *** & 0,145 & 0,103 & $0,692 * * *$ & 0,149 & 0,123 & 0,453 & 0,421 & 0,040 \\
\hline $\begin{array}{l}\text { Years of employment in the establishment } \\
\text { Industrial relations }\end{array}$ & $-0,004$ & 0,003 & $-0,001$ & $-0,002$ & 0,003 & 0,000 & $-0,008$ & 0,007 & $-0,001$ \\
\hline Existence of a works council ( $1=y e s)$ & $-0,416 * * *$ & 0,075 & $-0,069$ & $-0,417^{* * *}$ & 0,076 & $-0,074$ & $-0,390$ ** & 0,192 & $-0,034$ \\
\hline Member of a trade union ( $1=$ yes) & $-0,454^{* * *}$ & 0,095 & $-0,076$ & $-0,473^{* * *}$ & 0,107 & $-0,084$ & $-0,403$ & 0,272 & $-0,036$ \\
\hline $\begin{array}{l}\text { Member of a works council ( } 1=y e s) \\
\text { Establishment size: Ref. cat. less than } 20 \\
\text { employees }\end{array}$ & 0,025 & 0,147 & 0,004 & 0,056 & 0,156 & 0,010 & $-0,111$ & 0,494 & $-0,010$ \\
\hline 20 to 199 employees ( $1=$ yes) & $0,210^{* * *}$ & 0,076 & 0,035 & $0,191^{* *}$ & 0,084 & 0,034 & 0,162 & 0,181 & 0,014 \\
\hline 200 to 1999 employees ( $1=y e s)$ & $-0,032$ & 0,097 & $-0,005$ & $-0,057$ & 0,103 & $-0,010$ & $-0,150$ & 0,284 & $-0,013$ \\
\hline $\begin{array}{l}\text { More than } 2000 \text { employees ( } 1=y e s) \\
\text { Sector of industry: Ref. cat. manufacturing } \\
\text { industry, incl. construction }\end{array}$ & 0,012 & 0,104 & 0,002 & $-0,082$ & 0,111 & $-0,015$ & 0,384 & 0,247 & 0,034 \\
\hline Commerce, transport and catering industry ( $1=y e s)$ & $0,269 * * *$ & 0,080 & 0,045 & $0,362 * * *$ & 0,085 & 0,064 & $-0,492 *$ & 0,259 & $-0,043$ \\
\hline Other services ( $1=y e s)$ & 0,074 & 0,071 & 0,012 & 0,018 & 0,077 & 0,003 & 0,208 & 0,190 & 0,018 \\
\hline $\begin{array}{l}\text { Public service, education, health ( } 1=\text { yes) } \\
\text { Region }\end{array}$ & $-0,352 * * *$ & 0,086 & $-0,059$ & $-0,405 * * *$ & 0,097 & $-0,072$ & $-0,236$ & 0,194 & $-0,021$ \\
\hline East Germany ( $1=$ yes) & 0,015 & 0,065 & 0,002 & 0,027 & 0,069 & 0,005 & $-0,063$ & 0,171 & $-0,006$ \\
\hline Constant & $-1,943 * * *$ & 0,138 & & $-2,033^{* * *}$ & 0,152 & & $-2,230 * * *$ & 0,558 & \\
\hline
\end{tabular}

${ }^{*} p<0.1 ;{ }^{* *} p<0.05 ;{ }^{* * *} p<0.01$

Source: SOEP 2011, calculations by the author. Sample includes employees between 18 and 65 years. 


\section{English Questionnaire:}

Do you work overtime?

Yes $\bigcirc \quad$ No $\bigcirc \quad$ Not applicable, because I am self-employed

If you do not work overtime, is the work paid, compensated with time-off or not compensated at all?

Compensated with time-off

Partly paid, partly compensated with time-off

Paid

Not compensated at all

How was your situation with regards to overtime last month? Did you work overtime? If yes, how many hours?

Yes $\mathrm{O}$ hours, of which: hours were paid

No $\bigcirc$

What type of introduction or introductory training is usually necessary for this type of work?

Only a short introduction on the job

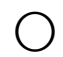

A longer training period in the company

Participation in special training or courses $\mathrm{O}$

Is your own performance regularly assessed by a superior as part of an agreed procedure? Yes $\bigcirc \quad$ No $\bigcirc$ 
Is your contract of employment for an unlimited or limited period?

Unlimited period

Limited period

Not applicable, do not have an employment contract

In your position at work, do you supervise others? In other words, do people work under your direction?

Yes $\mathrm{O}$

No $\mathrm{O}$

I will now read you some statements about possible job-related burdens of your current job. Please indicate whether each point applies to you and, if so, how much of a burden it is for you.

Applicable? And how much does it burden you?

No Yes Not at all Somewhat Heavily Very heavily

Because of the high volume of work,

there is often high time pressure.

$\bigcirc \quad 0 \quad 0 \quad 0 \quad 0$

I am often interrupted and distracted

while working.

$\bigcirc$

$\bigcirc$

$\bigcirc$

$\bigcirc$

$\bigcirc \bigcirc$

The amount of work has increased steadily

over the last two years.

$\bigcirc$
O
$\bigcirc$

O

$\bigcirc \bigcirc$

The chances of promotion in my company

are bad.

$\bigcirc$

$\bigcirc$

$\mathrm{O}$

$\bigcirc$

$\bigcirc$

O

I am undergoing - or I expect to undergo -

a worsening in my working situation.

$\bigcirc \bigcirc \quad 0$

My job is in jeopardy.

$\bigcirc$

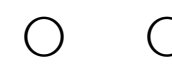

$\bigcirc$

O

○ $\bigcirc$ 